\title{
Decision Making In Higher Education to Support the Transportation and Logistics Industry in the 4.0 Era
}

\author{
Mustika Sari ${ }^{1}$, Raden Didiet Rachmat Hidayat ${ }^{2}$, Basri Fahriza ${ }^{3}$, Lut Mafrudhoh ${ }^{4}$ \\ ${ }^{1234}$ Faculty of Management and Business in Trisakti Institute of Transportation and Logistics, Jakarta, Indonesia
}

\begin{abstract}
In facing the competition of skilled labor between ASEAN member countries, Indonesia needs a quality workforce that is competitive. With good quality, the country's human resources are ready to compete in the ASEAN labor market. The purpose of this research is to find the best strategy that can be carried out by tertiary institutions in facing competition with other tertiary institutions to create graduates who can be absorbed in the industry. The research method uses the analytical hierarchy process (AHP). The model uses human perceptions that are considered experts in their fields and best understand the problems faced by the company and used literature review. The results of the study, three aspects become alternative strategies to support the sustainability of tertiary institutions in supporting the transportation and logistics industry, namely aspects of cooperation in the transportation and logistics industry, aspects of cooperation with overseas universities, and aspects of licensed international training certification. Of the three aspects, international training certification is the most important aspect of the strategy of supporting the sustainability of higher education institutions.
\end{abstract}

Keywords: Sustainability, Higher Education, Analytical Hierarchy Process.

\section{INTRODUCTION}

Education in Indonesia is organized through channels, levels, and types of education. The educational path is the process that students go through to develop their potential in an educational process that is in line with educational goals. There are three education channels namely, formal, nonformal, and informal education channels. Formal education is a structured and tiered education pathway consisting of basic education, secondary education, and higher education. Nonformal education is a channel of education outside of formal education that can be implemented in a structured and tiered manner [1].

There is an increasing trend that university graduates do not always find jobs easily. Students who have just graduated face intense competition in looking for work. The world of work also changes very quickly. Being a permanent employee of a company is no longer being pursued by the younger generation. The traditional career has been abandoned. Many new jobs did not exist in the previous 20 and 10 years and many industries moved to other countries [2]. The fact that exists today shows the quality of college graduates is not always acceptable and able to work as expected by the world of work. The rise of tertiary institutions has the potential to deteriorate the quality of graduates, given the standardization of graduate quality is not an objective but only seen from the aspect of the quantity that is how to get as many students as possible. Likewise with the implementation of campus autonomy; where state universities (PTN) and private (PTS) have similarities in management, so there is a tendency to find adequate funding but sometimes ignores the quality aspect itself [3].

The role of universities in the development of human resources is very large to be able to produce the best products. Lecturers are the main factor in carrying out the process of teaching and learning activities. Therefore lecturer career development must be considered, as a professional educator and scientific lecturer must run the higher education mandatory called Tridarma, namely: teaching, research, and community service [4].

In dealing with the competition of skilled labor between ASEAN member countries, it will certainly require a competitive quality workforce. The quality of the workforce must be supported by the quality of education held in each country. With good quality, the country's human resources are ready to compete in the ASEAN labor market. Vice versa if the quality of education is low then the human resources produced will be difficult to compete in the labor market. Looking at these conditions, universities have an important role to print competing human resources. Higher education institutions to provide workers who have the abilities and competencies needed by the market. Besides, quality universities will also be able to produce leaders and thinkers of a nation that determine the development of their country in the future.

The deciding factors in the effort to improve the quality of higher education in facing the ASEAN Community include vision and mission; the rules; governance guidelines; student body; human Resources; infrastructure; tri dharma college; international cooperation; visiting lecture; and the ASEAN issue. All of these factors are the basis in the management of higher education. [5]. Many experts in the field of human resources state that human resources are very important for the success of an organization and are the best investment and sustainable competitive advantage, unfortunately not all top management are convinced of this. World-class companies such as South Wales Airlines, General Electric, Microsoft Corp, believe that that human resources are indispensable assets and very serious investments that need to be effectively managed so they can become a competitive advantage [6]. 


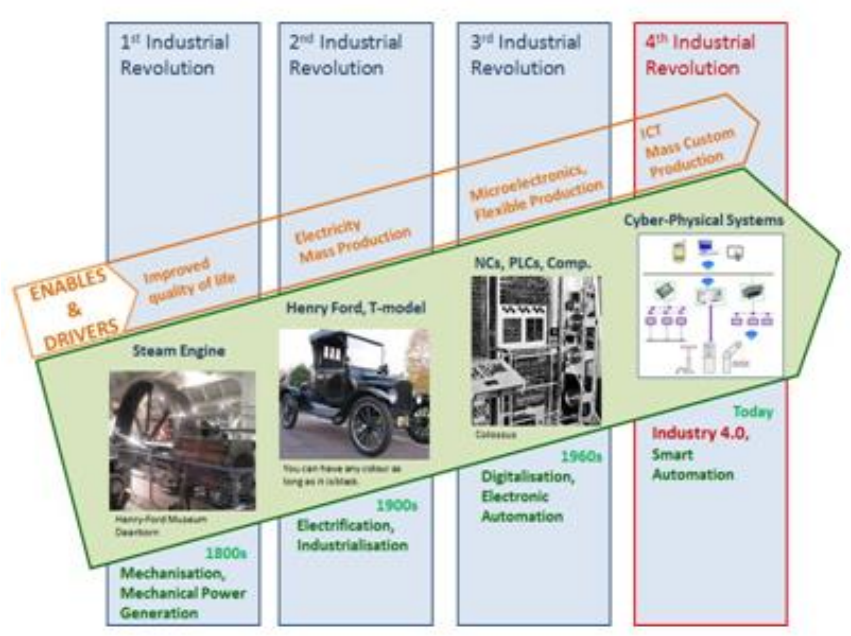

Fig 1:- Industrial Revolution Stages

The industrial revolution has developed from the industrial 1.0 era to the industrial 4.0 era. Starting from the industrial era 1.0 in 1800 which used mechanization technology and mechanical power generation. Followed by the 2.0 industrial era in 1900 which relied on electrification and industrialization. While the industrial era 3.0 which developed starting in 1960 relied on digitalization and electronic automation. The most recent development of the industrial revolution is industry 4.0 which has the characteristics of smart automation which was triggered by the development of Information and Communication Technologies (ICT). This industrial era started in Germany in 2011 at the Hannover Fair. This era puts forward the use of the internet and the Internet of Things (IoT). The influence of this last era is felt in the world and also in Indonesia. This was held by the proliferation of online businesses, platforms, cashless payments. Several offline businesses have also experienced the impact of this business era. [7]. Partnership for 21st Century Learning develops learning frameworks that require students to have skills, knowledge, and abilities in the fields of technology, media, and information, learning and innovation skills as well as life and career skills. This framework also explains the skills, knowledge, and expertise that must be mastered so that students can be successful in their lives and work [8].

\section{RESEARCH METHODS}

The Analytical Hierarchy Process (AHP) method was developed in the early 1970s [9]. The AHP model uses human perceptions that are considered experts in their fields and best understand the problems faced by the company and feel the effects of a problem or have an interest in the problem. The measurement of qualitative matters is very important given the increasingly complex problems around us with a higher level of uncertainty. Besides, AHP also tests the consistency of assessment [10]. To find out the criteria, sub-criteria, and strategies that are the most priority in the higher education model in supporting the transportation and logistics industry, there are three phases or stages of research to be carried out. The three phases are as follows:

\section{Model Construction}

The AHP model construction was compiled based on theoretical and empirical literature reviews, giving questions to experts and practitioners selected as informants or respondents, and through in-depth interviews to study information in more depth and obtain actual problems.

\section{Model Quantification}

The quantification stage of the model uses the questions in the AHP questionnaire in the form of pairwise comparison between elements in the cluster to find out which of the two has greater influence (more dominant) and how big the difference is through the numerical scale 1-9. The assessment data is then collected and inputted through expert choice 11.0 software to be processed to produce priority and matrix outputs. The results of each respondent will be inputted on a separate AHP network.

\section{Synthesis and Analysis}

In conducting synthesis and analysis geometric instruments are used or geometric averages. Geometric Mean is used to determine the results of individual assessments of the respondents and determine the results of opinions in one group [11].

The other method used is a literature review or literature study. The literature review serves to build concepts or theories that form the basis of studies in research [12]. A literature review is an activity that has the main objective of developing both the theoretical and beneficial aspects of service [13].

Meanwhile, to obtain correct and precise results in analyzing data, content analysis techniques are used, which are in-depth discussions of the contents of written or printed information. This technique can be used to analyze all forms of communication or other documentation material [14].

\section{RESULT AND DISCUSSION}

To find answers to research questions while achieving research objectives, namely knowing the university's sustainability strategy in supporting the transportation and logistics industry.

Data is collected using interviews assisted by questionnaires. In interviews with informants, a pairwise comparison method will be conducted. The pairwise comparison method is used to determine the weight of each indicator. Determination of the weight is done by submitting a questionnaire that is open to the informant. Clusters and nodes are used to support decision making in the Analytical Hierarchy Process method. In this study, the cluster is divided into 3, namely: Criteria, Sub-Criteria, and Strategy. The research objective is to know the university's sustainability strategy in supporting the transportation and logistics industry, while the criteria consist of 3 aspects namely: Life and career skills, Learning skills and innovation, and Technology and ICT Skills. The final cluster is an alternative strategy consisting of 3 alternative strategies, namely: (1) aspects of cooperation in the 
transportation and logistics industry, (2) aspects of cooperation with overseas universities, and (3) aspects of international training certification licensing.

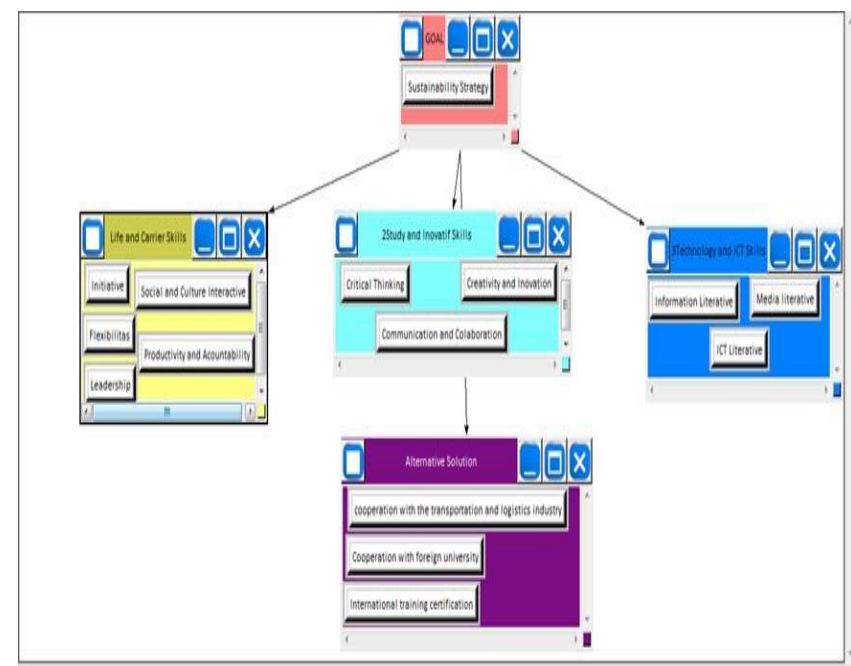

Fig 2:- AHP Model Structure

The survey results obtained based on the results of the questionnaire were processed in advance for each respondent by using the AHP framework to parse the criteria, sub-criteria, and strategies that are the most priority in the college sustainability model in supporting the transportation and logistics industry. The framework model also forms the basis of questionnaires. Data processed from each of these respondents produce two matrices that will give priority order criteria and appropriate alternatives in the opinion of each respondent. The synthesis results of the average respondent from 10 experts will be grouped into 3 findings, namely priority criteria, sub-criteria, and priority priorities for the university's sustainability strategy in supporting the transportation and logistics industry.

Based on the picture below, there are three aspects of the criteria to support the university's sustainability strategy, namely, aspects of life and career skills, aspects of learning and innovation skills, and aspects of technology and ICT skills. Of the three aspects, aspects of technology and ICT skills are the main priorities in supporting the university's sustainability strategy with a weighting value of 0.386 , followed by aspects of learning skills and innovation with a weighting value of 0.313 , and aspects of life and career skills as the last priority with a weighting value amounted to 0.301 .

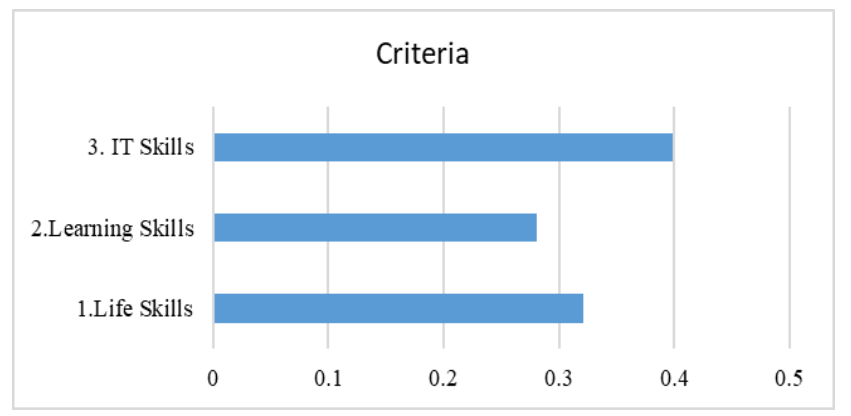

Fig 3:- Criteria Cluster
This result is relevant to the research conducted by several researchers, for example, the implementation of active learning can be focused on an alternative learning procedure that encourages each student to be actively involved in each group task completion and is always active to listen, record the core of lecture material, listen and reconceptualizing or reflecting on every material that is being presented and discussed in the learning process in class, and conditioning so that every student is always ready at any time to re-present in his own words the material that has been discussed and discussed. To that end, learning procedures can be developed into 8 stages as follows: (1) orientation, (2) group formation, (3) group work assignments, (4) exploration, (5) presentation of material in class, (6) checking understanding and material deepening, (7) reflection and feedback, and (8) formative evaluation [15]

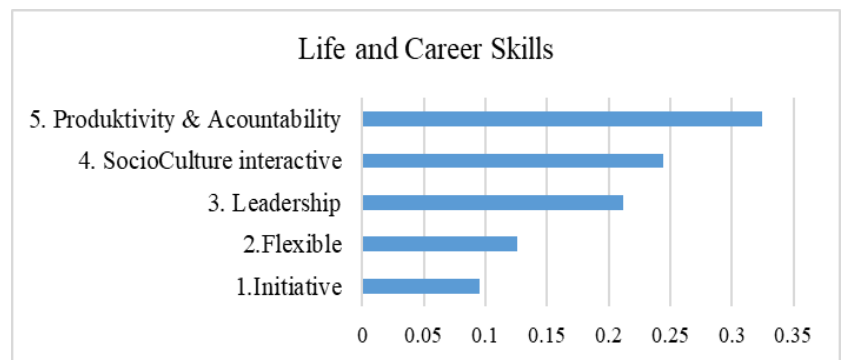

Fig 4:- Life and Career Skills Cluster

To explain picture 3 , the image is made with each criterion. These are the criteria cluster, cluster life, and career skills, learning and innovation skills, and technology skills. Based on the picture above, there are five aspects to life and career skill clusters namely, initiative, flexibility, leadership, socio-cultural interaction, and productivity and accountability. Of the three aspects, productivity and accountability aspects are the main priorities in improving life and career skills with a weight value of 0.256 , followed by aspects of socio-cultural interaction with a weight value of 0.204 as a second priority, leadership aspects with a weight value of 0.203 as the third priority, the flexibility aspect with a weight value of 0.169 as the fourth priority, and the initiative aspect with a weight value of 0.168 as the last priority. This result is relevant to the research that has been carried out by several researchers, In human resource management, it is stated that every person in an organization has the right to develop themselves to improve and progress their career.

There are six steps to career development that can be done individually, namely; a) Job performance, Career progress is very dependent on performance, b) Exposure Career progress is determined by exposure, that is, being known, by people who are authorized to decide on promotions, transfers, and other career opportunities. Without exposure, employees who excel may not get the opportunity to achieve their career goals, c) Demand stops. an employee changes work to a more promising place. This way, for some professional managers, considered part of a strategy to improve their careers, d) Loyalty to the organization Loyalty to the organization also determines the 
progress of the career concerned, e) Mentors and sponsors. If the mentors succeed in guiding the careers of lecturers and junior employees, then the mentors can become their sponsors below, f) The opportunity to develop can be achieved when the staff and lecturers can improve their scientific abilities and skills [16].

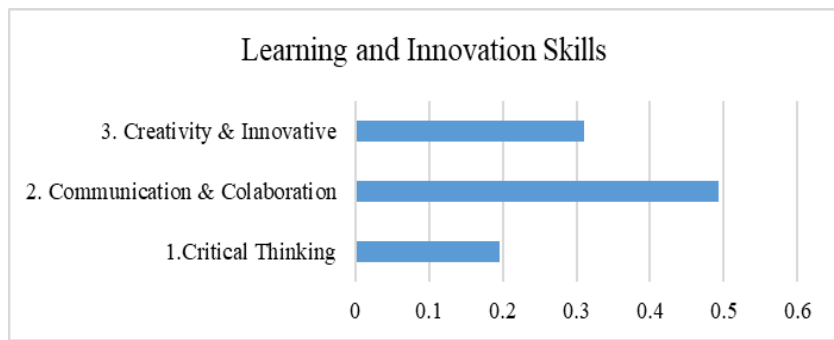

Fig 5:- Learning and Innovation Skills Cluster

Based on the picture above there are three aspects that support learning and innovation skills, namely aspects of critical thinking, aspects of communication and collaboration, as well as aspects of creativity and innovation. Of the three aspects, communication and collaboration aspects are the main aspects in supporting learning and innovation skills with a weight value of 0.365 , followed by creativity and innovation with a weight value of 0.347 , and critical thinking aspects being the lowest aspect with a weight value of 0.288

These results are relevant to research that has been done by several researchers, for example, the creation of ideas and evaluative thinking can be implemented. The learning process in higher education should be studentcentered and student activeness, where the lecturer acts more as a facilitator/ mediator and motivator who uses to stimulate students to learn something meaningful through understanding (insight). For this reason, the learning approach used is based on experience (experience is the only basis for knowledge and tourism). In the business world, the collaboration model is not only for the ranks of the company's employees, consumers can also be included in the global idea gathering system. PnG (one of the multi-national companies) opens consumer channels to convey and discuss new product ideas with their innovations which are named connect and develop [17].

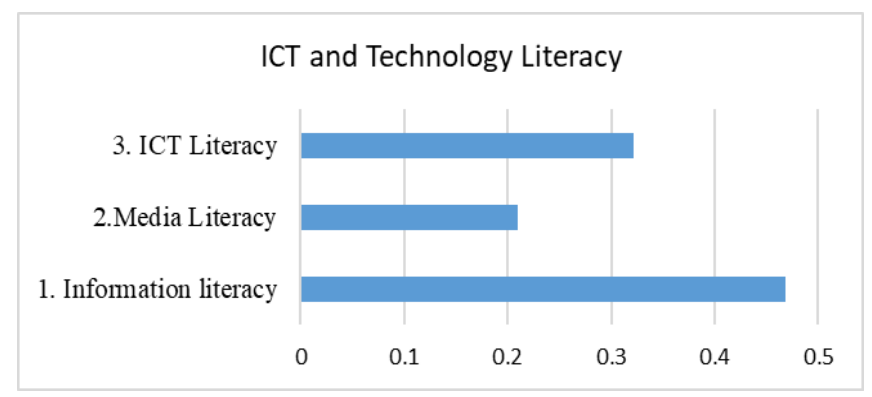

Fig 6:- Technology and ICT Literacy Cluster
Based on the picture above, three aspects support technology and ICT skills, namely aspects of information literacy, aspects of media literacy, and aspects of ICT literacy. Of these three aspects, information literacy is the most important aspect in supporting technology and ICT skills with a weight value of 0.362 , followed by ICT literacy aspects with a weight value of 0.348 , and media literacy aspects with a weight value of 0.291 as the lowest aspect.

This result is relevant to research that has been conducted by several researchers, for example Observing the nine pillars of character that underlie character education most are included in the affective domain or related to selfsystem [18]. Whereas so far most of the important opinion in science education is the mastery of subject matter (content, knowledge, concepts). Knowledge of subject matter is only a vehicle to develop thought processes and other related matters in it. If it is said that science is a product, the process and application with attitudes and values in it then concern the three domains in education. Usually, the greatest weight is given to the cognitive aspect of reasoning. Included in reasoning are logical thinking, rational thinking, critical thinking, creative thinking, making decisions. Some even distinguish it from basic thinking and complex thinking (Presseissen in Costa, 1985). Logical thinking and rational thinking include basic thinking, while critical thinking, creative thinking, making decisions including complex thinking [18].

The US-based Apollo Education Group identifies ten (10) skills needed by students to work in the 21 st century, namely critical thinking skills, communication, leadership, collaboration, adaptability, productivity and accountability, innovation, global citizenship, ability, and soul entrepreneurship, as well as the ability to access, analyze and synthesize information (Barry, 2012). Based on the results of research conducted by the OECD obtained descriptions of three (3) dimensions of learning in the $21 \mathrm{st}$ century, namely information, communication, and ethics, and social influence (Ananiadou \& Claro, 2009). Creativity is also an important component in being able to successfully face a complex world (IBM, 2010) [19].

Based on the picture below, three aspects become alternative strategies to support the sustainability of tertiary institutions in supporting the transportation and logistics industry, namely aspects of cooperation in the transportation and logistics industry, aspects of cooperation with overseas universities, and aspects of international training licensing certification. Of the three aspects, international training certification is the most important aspect in the strategy to support the sustainability of tertiary institutions with a weighting value of 0.347 , followed by aspects of establishing cooperation with the transportation and logistics industry with a weighting value of 0.344 , and cooperation with foreign universities being the lowest aspect with a weight value of 0.309 . 


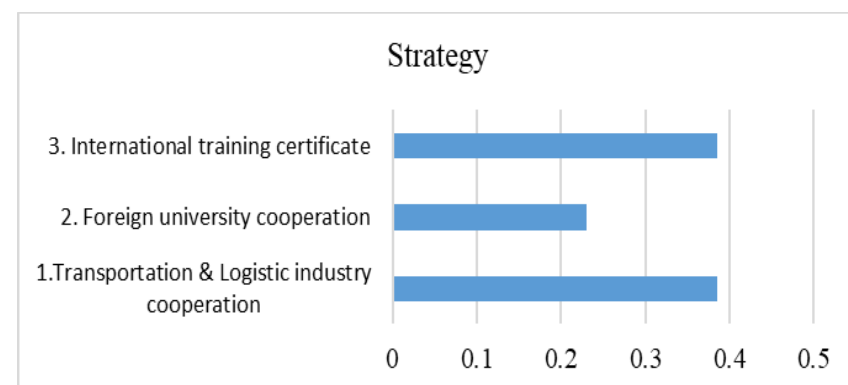

Fig 7:- Strategy Cluster

This result is relevant to the research conducted by several researchers. Cooperation in building partnerships between the industrial world and educational institutions will be a great force to win the competition in the global market. By making educational institutions as partners, the results of educational products can be enjoyed by businesses and industries to increase business profits. With the support of industry, educational institutions will no longer produce educated unemployment as has always been the subject of discussion at LPTK. So finally the unemployment case will be resolved. With the support of the industry, educational institutions will produce business commodity products that can encourage the growth of entrepreneurship and business innovation for the industry in penetrating the global market [20].

This can be realized by pursuing a curriculum with the following information: 1) Industry aligned curriculum, 2) Training support schemes to help business access programs, 3)

Prepare job-ready graduates by integrating work experiences as part of their courses, 4) Competent professionals with soft skills.

The curriculum that will be made should be based on best practices in the related industry so that it links and matches the needs. For the basic supply chain concept, which is also the core management skills, the operational skills are as follows: 1) Sourcing \& procurement, 2) Production planning, 3) Warehouse management, 4) Inventory management, 5) Transportation management [21].

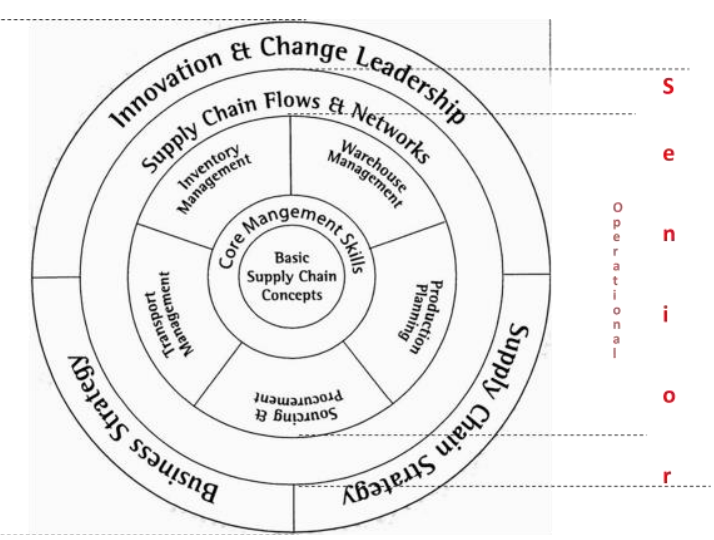

Fig 8:- European Logistics Association (ELA) Curriculum
For example, industry certification issued by ELA can be applied as a role model. The levels are: 1) EJLog for supervisors in an operational and for first-line managers level for undergraduate student, 2) ESLog for senior management level for the graduate student, and 3) EMLog for strategic management level for doctoral student [21].

5 (five) skills expected by the industry in the field of transportation and logistics to become a standard body of knowledge, namely: thinking and learning, interpersonal, customer service, and business skills [22]. However, we consider expanding the idea into a broader area. The complete idea is 1) Thinking and learning, 2) Interpersonal, 3) Customer service and business, 4) Analytical and ICT, 5) Logistics/Supply Chain business skill specialist.

Thinking and learning are expected that education graduates in the field of Transportation and Logistics already have a mindset of thinking about transportation and logistics goals, namely profit-oriented by using a way of reducing costs without reducing quality.

Interpersonal, it is hoped that education graduates in the field of transportation and logistics will already have a mindset that this business is a people business where a lot of personal interaction is involved.

Customer services and business is expected that education graduates in the transportation and logistics sector will have a hospitality mindset and a desire to provide the best service.

Analytical and ICT is expected that education graduates in the field of transportation and logistics have a mindset to maximize the use of analysis and ICT to serve customers and perfect orders and zero defects. We consider this is already mandatory in the 4.0 industry era [23]-[25].

Logistics/Supply Chain Specialist is expected that education graduates in the field of transportation and logistics have chosen specializations in fields such as oil and gas logistics, humanitarian logistics, halal logistics, manufacturing logistics, and other related logistics. Not only in the 3rd Party Logistics (3PL) fields [23], [25]-[31].

As for the foundation, the 5 (five) critical abilities developed through qualifications and/or experiences. This means that the abilities mentioned above are obtained from the qualifications and experiences of practitioners, of course, also without forgetting the theoretical basis.

In other words, the education curriculum is expected to be based on 1) Vocational education: skilled in using hand skills. With a laboratory or practical composition of around $60 \%-70 \%$, 2) Academic education: skilled in thinking with analytical skills with an emphasis on analytical skills.

Our campus has an important role because its position is between the desires of the industry and its position as education. Thus it is not surprising that a curriculum in the field of transportation and logistics should be made with due 
observance of input from practitioners by using the standards body of knowledge as described above [32].

\section{CONCLUSION}

Three aspects of the criteria that support the university's sustainability strategy are, aspects of life and career skills, aspects of learning and innovation skills, and aspects of technology and ICT skills. Of the three aspects, aspects of technology and ICT skills are the main priorities in supporting the university's sustainability strategy with a weighting value of 0.386 , followed by aspects of learning skills and innovation with a weighting value of 0.313 , and aspects of life and career skills as the last priority with a weighting value amounted to 0.301 .

Three aspects become alternative strategies to support the sustainability of tertiary institutions in supporting the transportation and logistics industry, namely aspects of cooperation in the transportation and logistics industry, aspects of cooperation with overseas universities, and aspects of international training certification licensing. Of the three aspects, international training certification is the most important aspect in the strategy to support the sustainability of tertiary institutions with a weighting value of 0.347 , followed by aspects of establishing cooperation with the transportation and logistics industry with a weighting value of 0.344 , and cooperation with foreign universities being the lowest aspect with a weight value of 0.309 .

5 (five) skills expected by the industry in the field of transportation and logistics to become a standard body of knowledge, namely: 1) Thinking and learning, 2) Interpersonal, 3) Customer service and business, 4) Analytical and ICT, 5) Logistics/Supply Chain business skill specialist.

\section{REFERENCES}

[1]. S. B. Raharjo, "Evaluasi Trend Kualitas Pendidikan di Indonesia," J. Pendidik. dan Eval. Pendidik., vol. 2, no. 16, pp. 511-532, 2012.

[2]. Stephen Fallows and C. Steven, "Building Employability Skills into The Higher Education Curriculum: A University-Wide Initiative," 2000.

[3]. M. Asmawi, "Strategi Meningkatkan Lulusan Bermutu di Perguruan Tinggi," Makara, Soc. Hum. J., vol. 9, no. 2, pp. 66-71, 2005.

[4]. M. Prasetyo, Suharsono, "Strategi Pengembangan Sumber Daya Manusia di 5 Perguruan Tinggi Dalam Menghadapi Persaingan Gloal," 2017.

[5]. F. Nulhaqim, Heriyadi, Pancasilawan, "Peranan perguruan tinggi dalam meningkatkan kualitas pendidikan di indonesia untuk menghadapi asean community 2015," Soc. Work, vol. 0042, 2015.

[6]. Luthans \& Youssef, "Human, Social, and Now Positive Psychological Capital Management: Investing in People for Competitive Advantage," 2004.
[7]. R. D. R. Hidayat, S. Marina, A. Rahmawati, R. Fauzi Jayasakti, and L. Agusinta, "Peranan Menwa Dalam Character Building Untuk Keunggulan Bersaing di Industri 4.0," Pros. PKM-CSR, vol. 2, pp. 722-728, 2019.

[8]. N. Wijaya, Sudjimat, "Transformasi Pendidikan Abad 21 Sebagai Tuntutan Pengembangan Sumber Daya Manusia di Era Global," Pros. Semin. Nas. Pendidik. Mat., vol. 1, pp. 263-278, 2016.

[9]. T. L. Saaty, "The Analytic Hierarchy Process: Decision Making in Complex Environments," Quant. Assess. Arms Control, pp. 285-308, 1984.

[10]. irawan \& M. Julianti, "Pemilihan Guru Berprestasi Menggunakan Metode AHP dan Topsis," in Prosiding Seminar Nasional Penelitian, Pendidikan dan Penerapan MIPA, 2011, pp. 63-68.

[11]. T. L. Saaty, "Decision Making With The Analytic Hierarchy Process," Int. J. Serv. Sci., vol. 1, no. 1, 2008.

[12]. W. V Sujarweni, Metodologi Penelitian: Lengkap, Praktis, dan Mudah Dipahami, 2nd ed. Jogyakarta: Pustaka Baru Pers, 2014.

[13]. Sukardi, Metodologi Penelitian Pendidikan: Kompetensi dan Praktiknya. Jakarta: PT Bumi Aksara, 2013.

[14]. Afifuddin and B. A. Saebani, Metodologi Penelitian Kualitatif. Bandung: Pustaka Setia, 2009.

[15]. A. Muhtadi, "Kemitraan Antara Dunia Industri dan Pendidikan Dalam Pengembangan SDM PTK," in FIP Universitas Negeri Yogyakarta, 2015, pp. 1-12.

[16]. C. Alba, "Strategi Peningkatan Mutu Pendidikan di Perguruan Tinggi," J. Sosioteknologi, no. 24, 2011.

[17]. H. Subekti, "Perspektif Menyiapkan Lulusan Yang Adaptif Untuk Mendukung Keterampilan Abad 21 Dalam Perkuliahan Bioteknologi," J. Florea, vol. 1, no. 2, pp. 26-29, 2014.

[18]. N. Y. Rustaman, "Pendidikan dan Penelitian Sains Dalam Mengembangkan Ketrampilan Berpikir Tingkat Tinggi Untuk Pembangunan Karakter," in Seminar Nasional VIII Pendidikan Biologi, 2008, pp. 15-34.

[19]. S. Zubaidah, "Keterampilan Abad Ke-21: Keterampilan Yang Diajarkan," Univ. Negeri Malang, no. 2, pp. 1-17, 2016.

[20]. H. Uswatun, "Kemitraan Antara Dnia industri dan Pendidikan Dalam Pengembangan SDM PTK," in Seminar Internasional, ISSN 1907-2066 Peran LPTK Dalam Pengembangan Pendidikan Vokasi di Indonesia, 2004, pp. 613-620.

[21]. ELA, "European Logistics Association (ELA)," Concept of the ELA Certification, 2020. [Online]. Available: https://www.elalog.eu/concept-elacertification. [Accessed: 25-Sep-2020].

[22]. C. Chan, I. N. Pujawan, and M. Rianto, "An Employment-Focused Curriculum Framework to Close Skills Gaps Among Supply Chain Professionals," in Proceedings of the 9th International Conference on Operations and Supply Chain Management (OSCM), 2019. 
[23]. R. D. R. Hidayat, S. Marina, L. Agusinta, A. Setyawati, and A. Rahmawati, "The Development of Online Platform for Humanitarian Logistics," Proc. 9th Int. Conf. Oper. Supply Chain Manag., pp. 1-8, 2019.

[24]. G. T. Nugraha, R. D. R. Hidayat, T. Budiman, and A. Setiawan, "The Implementation of Halal Supply Chain With Private Blockchain in Indonesia," Adv. Transp. Logist. Res., vol. 1, no. 1, pp. 174-186, 2018.

[25]. J. C. Zain, G. T. Nugraha, R. D. R. Hidayat, and T. Budiman, "The Implementation of Halal Supply Chain With Private Blockchain in Indonesia," Adv. Transp. Logist. Res., vol. 1, no. 1, pp. 174-186, 2018.

[26]. W. Rizaldy, R. D. R. Hidayat, and L. D. Handayani, Manajemen Rantai Pasok dan Logistik (Berdasarkan Aturan Nasional, Internasional, dan Review Para Pakar), 1st ed. Bogor: In Media, 2018.

[27]. R. D. R. Hidayat, "The Readiness of Halal Certified Logistics Services Provider Company to Support Halal Industry in Indonesia," in Contemporary Issues on Halal Development in Indonesia, 1st ed., Malang: Global Science, 2020, pp. 204-211.

[28]. R. D. R. Hidayat et al, Logistik Halal (Kompilasi Berbagai Pemikiran), 1st ed. Bogor: In Media, 2019.

[29]. R. D. R. Hidayat, O. Febri, E. Saribanon, A. Rahmawati, and S. Marina, "Peran Aktif Institut Transportasi dan Logistik (ITL) Trisakti Dalam Meningkatkan Kesadaran Manajemen Kebencanaan di Indonesia," Pros. PKM-CSR, vol. 1, pp. 958-964, 2018.

[30]. R. D. R. Hidayat, B. Fahriza, L. Agusinta, A. Setyawan, and S. Marina, "Study of the formation of National Logistics Cluster for Disaster Management (KLASNASLOG PB) by National Disaster Management Authority (BNPB) to Streamline Transport for Disaster Management in Indonesia," in MATEC Web of Conferences, 2018, vol. 229, pp. 1-6.

[31]. R. D. R. Hidayat, W. Rizaldy, L. Lesmini, F. Mastarida, and H. Yasni, "Pemodelan Pusat Logistik Berikat (PLB) Untuk Halal Cold Chain Warehouse di Indonesia," in Digitalisasi SCM Pada Produk Kreatif, 1st ed., E. Kusrini, N. I. Arvitrida, and G. A. Widyadana, Eds. Jogyakarta: Kepel Press, 2020, pp. 19.

[32]. I. Trisakti, "Trisakti Institute of Transportationa and Logistics," 2020. [Online]. Available: http://itltrisakti.ac.id/. [Accessed: 24-Sep-2020]. 